\title{
Large mammals surviving conflict in the eastern forests of Afghanistan
}

\author{
Kara Stevens, Alex Dehgan, Maria Karlstetter, Farid Rawan \\ Muhammad Ismail Tawhid, Stephane Ostrows Ki, Jan Mohammad Ali \\ and Rit A Ali
}

\begin{abstract}
We used transect and camera-trap surveys and DNA identification of scat samples to provide the first update since 1977 of large mammals in the montane forests of the conflict-ridden province of Nuristan in eastern Afghanistan. Nuristan contains a range of habitats from oak Quercus spp. forests to treeless alpine steppes that historically hosted populations of markhor Capra falconeri, Asiatic black bear Ursus thibetanus, grey wolf Canis lupus and common leopard Panthera pardus, among others. Surveys conducted in 2006-2009 in an area of $1,100 \mathrm{~km}^{2}$ by the Wildlife Conservation Society confirmed the presence of some of these species, and also recorded the common palm civet Paradoxurus hermaphroditus, previously unknown from Afghanistan; this extends the westernmost boundary for this species. The most commonly recorded species, as determined by direct sightings, scat identification or camera-trap photographs, were the Indian crested porcupine Hystrix indica, red fox Vulpes vulpes and a canid (grey wolf or golden jackal Canis aureus). Despite indications of significant habitat loss and unsustainable hunting, globally important species persist in the area and targeted conservation programmes are required for the protection of these species, the forests they inhabit and the surrounding communities who depend on both for their survival.
\end{abstract}

Keywords Afghanistan, camera trap, civet, DNA analysis, Nuristan, post-conflict, wildlife

Kara Stevens (Corresponding author) ${ }^{*}$, Alex Dehgan ${ }^{\dagger}$, Maria Karlstetter $^{\ddagger}$, Farid Rawan ${ }^{\zeta}$, Muhammad Ismail Tawhid ${ }^{\pi}$ and STEPHANE OstrowsKI ${ }^{* *}$ Shar-e-Nau, Kabul, Afghanistan. E-mail stevenskara@ yahoo.com

Jan Mohammad Ali and Rita Ali Wildlife Conservation Society, Waygal, Nuristan, Afghanistan

${ }^{*}$ Current address: Michigan State University, 13 Natural Resource Building, East Lansing, MI 48824, USA

${ }^{\dagger}$ Current address: United States Agency for International Development, Washington, DC, USA

${ }^{\ddagger}$ Current address: Fauna \& Flora International, Cambridge, UK

${ }^{8}$ Current address: University of Nangarhar, Jalalabad, Nangarhar, Afghanistan

"Current address: Wildlife Conservation Society, Kabul Afghanistan

${ }^{*}$ Current address: Wildlife Conservation Society, Bronx, NY, USA

Received 29 December 2009. Revision requested 10 March 2010.

Accepted 7 May 2010.

\section{Introduction}

Turistan Province in eastern Afghanistan contains an extensive portion of the country's remaining deciduous and coniferous forests, which harbour a diverse assemblage of wildlife. Extensive deforestation, hunting and lax regulation pose serious threats to the persistence of Afghanistan's eastern forests and wildlife, among which are five globally threatened large mammal species: snow leopard Panthera uncia, markhor Capra falconeri, urial Ovis orientalis, musk deer Moschus cupreus and Asiatic black bear Ursus thibetanus (IUCN, 2010).

Prior to the study reported here the last comprehensive review of Nuristan's wildlife was in 1977 when a 6-week mission studied the viability of a potential markhor trophyhunting programme in the region (Petocz \& Larsson, 1977). The mission made direct observations of markhor and ibex Capra sibirica and, although c. 350 markhor were observed, it was estimated that a much larger population existed in the area (Petocz \& Larsson, 1977). Natural history expeditions in the 1960s suggested that two felid species (common leopard Panthera pardus and leopard cat Prionailurus bengalensis), three canid species (the grey wolf Canis lupus, golden jackal Canis aureus and red fox Vulpes vulpes) and four ungulate species (ibex Capra ibex, urial, musk deer and markhor) occur in Nuristan (Hassinger, 1973). It has also been suggested that Nuristan harbours two species of bear: Asiatic black bear and brown bear Ursus arctos (Hassinger, 1973). Habibi (2003) suggested that Nuristan includes the range of four further felid species (snow leopard, lynx Lynx lynx, wildcat Felis silvestris and Pallas's cat Otocolobus manul).

A proliferation of modern weaponry combined with the breakdown of traditional management practices for natural resources because of persistent conflict over the past 30 years has imperilled these wildlife populations. To understand better the effects of 30 years of conflict on the persistence of these species and to develop a baseline for conservation management, the Wildlife Conservation Society (WCS) conducted camera-trap surveys, transect surveys for large mammals and scat collection surveys in south central Nuristan Province.

\section{Study area}

The study site is a forested area in south central Nuristan straddling the border of Kunar Province, comprising 
c. $1,100 \mathrm{~km}^{2}$ and an approximate altitude range of 1,070$4,500 \mathrm{~m}( \pm 90 \mathrm{~m}$, determined from the Shuttle Radar Topography Mission Digital Elevation Model available from Global Land Cover Facility, 2010). We overlaid a grid of 27 squares of $50 \mathrm{~km}^{2}$ over the study site; not all the grids covered forest (Fig. 1).

The area is historically characterized by extended oak Quercus spp. forests up to 2,500 $\mathrm{m}$, where they are displaced by coniferous forests comprising juniper Juniperus spp., pine Pinus spp. and deodar cedar Cedrus deodara. The tree line is at 3,600 $\mathrm{m}$ and, above that, there are alpine shrublands, heaths and meadows (Petocz \& Larsson, 1977). There have been no recent assessments of forest or rangeland condition, although UNEP (2003) estimated that the region containing Nuristan and two bordering provinces of Kunar and Nangarhar have lost $52 \%$ of their forests in the last 30 years.

\section{Methods}

Survey teams comprised people from Nuristan and neighbouring provinces, led in the field by FR, MIT, JMA and RA. The team members represented a combination of provincial Department of Agriculture staff, Nuristani community leaders recognized for their knowledge of the region's flora and fauna, and University of Nangarhar-trained veterinarians. Because the security situation did not allow non-Afghan staff to accompany teams in the field KS and AD trained the teams in and around the capital, Kabul, for 20 days in November 2006, in survey methodologies, navigation, use of a global positioning system, digital camera, rangefinder, binoculars and data sheets and in scat collection methodology until all three teams demonstrated consistent competence. $\mathrm{KS}, \mathrm{AD}, \mathrm{MK}$ and $\mathrm{SO}$ trained and evaluated team members throughout the duration of the surveys.

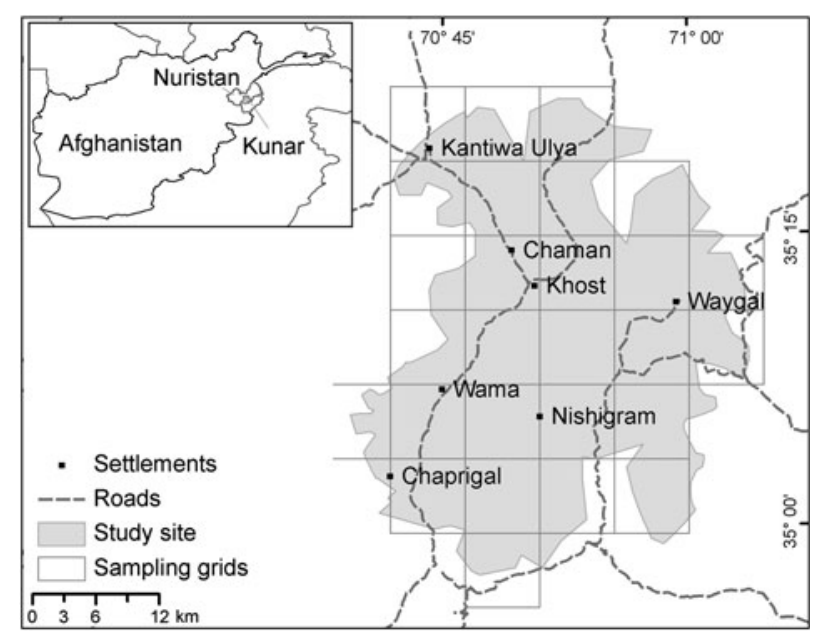

FIG. 1 The study site in south central Nuristan Province, Afghanistan. The shaded area on the inset indicates the location of the main map.
Transect surveys for large mammals were conducted during four periods between December 2006 and May 2007. Each of the $2750-\mathrm{km}^{2}$ grid cells was subdivided into 16 sub-cells of equal size, and one random sub-cell was selected, prior to beginning the survey, as a starting point. Teams attempted to reach the start point, when security conditions would allow, and from there utilize stream courses, animal trails and abandoned footpaths as survey transects. The search effort expended was approximately proportional to the extent of forest cover in each grid cell. The planned transect length in each grid cell was based on the extent of forest cover, with $1 \mathrm{~km}$ of transect per $10 \%$ of cover; i.e. if a grid had $40 \%$ forest cover the teams aimed to walk $4 \mathrm{~km}$. Some grids, however, were surveyed less because of security problems. In grids without security problems, teams were able to cover a greater distance than planned.

Teams surveyed 25 of the 27 grid cells, maximizing early morning hours when possible to increase opportunities to encounter wildlife. In total 115 transects were surveyed in a total survey time of c. 350 hours, noting evidence of species occurrence such as sightings, signs, tracks, scats and carcasses. Because of the difficulties of distinguishing the tracks of similar species such as red fox, golden jackal and grey wolf, we only report evidence from direct sightings and scats, where species identification could be confirmed through DNA analysis. Using hip chains to measure distance, teams walked 4-25 $\mathrm{km}$ of transects per grid cell for a total of $368 \mathrm{~km}$ of transects.

Teams also conducted three camera-trap surveys in August 2007, November-December 2007 and January March 2009 in six of the $50-\mathrm{km}^{2}$ grid cells that, according to residents and survey teams, had intact forest cover and evidence of common leopard. Ten camera traps were placed in five pairs to estimate minimum population size of the common leopard using capture-recapture techniques (Henschel \& Ray, 2003; Jackson et al., 2006), as well as to record evidence of other species. Cameras were placed perpendicular to trails, on opposite sides, to capture photographs of the uniquely identifiable pelage patterns on both flanks of the common leopard (Henschel \& Ray, 2003; Jackson et al., 2006). All cameras were placed within oak and coniferous forests. During each survey Wildlife Pro (Model WLP; Forestry Suppliers, Inc., Jackson, USA) and Deer Cam (Model DC 300, Non-Typical, Inc., Park Falls, USA) pairs of camera traps were positioned $40-50 \mathrm{~cm}$ above ground, a maximum of $5 \mathrm{~m}$ apart, in 9-10 sites per grid cell, totalling 97 sites. Initial placement of camera traps in August 2007 resulted in clustered sites relatively close to villages and without adequate coverage of the grid. In November 2007 the same grids were resurveyed to achieve a wider distribution of sites. With little information on the demographic parameters of the common leopard in Nuristan we used a relatively short sampling period to meet the assumption of a closed population, to ensure adequate 
battery life and film, and to reduce the opportunity for theft. After 10 days of trapping the five camera pairs were moved to another five sites within the grid cell. Sites were at least $500 \mathrm{~m}$ apart but preferably $1 \mathrm{~km}$ apart and at altitudes of 1,150-3,463 $\mathrm{m}$ (mean $=2,238 \pm \mathrm{SD} 509 \mathrm{~m}$ ). The number of trap nights per site was $3^{-14}$ (mean $=9.3$ nights \pm SD 2.3), totalling 901 trap nights. Traps were not baited, although a goatskin found along a trail was placed in front of one camera pair for a 5-night period.

During the transect surveys, and incidentally during camera-trap surveys, teams collected scat samples $(n=201)$ for DNA analysis. Being uncertain of the ability of teams to discern scats of different species, we encouraged them to collect all scats. After collection scat samples were air-dried away from direct sunlight and stored in labelled plastic bags at ambient temperatures. Samples from all scats were sent to the Global Felid Genetic Program at the American Museum of Natural History, New York, USA, for identification. The laboratory retrieved DNA from sloughed intestinal epithelial cells of faecal samples (Foran et al., 1997). Each sample was amplified and analysed using polymerase chain reaction (PCR) techniques, pursuant to standard microsatellite amplification protocols described in the QIAGEN Multiplex Kit (QIAGEN, Hilden, Germany) for the following microsatellite primers: FCA032 F and R, FCA1oo F and R, FCA124 F and R, FCA126 F and R, FCA212 F and R, FCA229 F and R, FCA096 F and R, FCA132 F and R, FCA275 F and R, FCA107 $\mathrm{F}$ and R, FCA208 F and R, FCA075 F and R, and FCA225 F and R (Waits et al., 2007). The PCR was conducted in Eppendorf Gradient $S$ Mastercycler machines, sequenced on an $\mathrm{ABI}_{3730}$ Sequence Machine, using the Formamide/LIZ 500 protocol (ABI, Applied Biosystems, Foster City, USA), and analysed using GeneMapper v. 4.o (ABI, Applied Biosystems, Foster City, USA). 12S, 16 S and Cytochrome B mitochondrial ribosomal RNA subunits were analysed to identify species more accurately using molecular data from NCBI (2010). Each identified target species was reconfirmed by genotyping each sample two times and repeating the process five times for each sample that failed.

Survey teams consulted community members extensively during the study, using both formal and informal methods. The teams conducted $>150$ household interviews with selfidentified hunters and a non-random selection of people who were knowledgeable about wildlife. Interviewees were questioned on the extent of depredation on livestock, evidence of occurrence of large mammal species (sighting, signs, secondary signs or no evidence) and observed trends in carnivore abundance over the previous 10 years (increasing, decreasing or no change), as well as their hunting activities.

\section{Results}

We obtained evidence (photographs from camera traps, scat DNA analysis and/or direct sightings) of the presence of leopard cat, grey wolf, golden jackal, red fox, Asiatic black bear, markhor, rhesus macaque Macaca mulatta, Indian crested porcupine Hystrix indica, common palm civet Paradoxurus hermaphroditus (the first record of this species in Afghanistan) and yellow-throated marten Martes flavigula. Camera traps captured three photographs of an unidentifiable small cat that was either a domestic Felis catus or wild cat $F$. silvestris. There were no sightings or faecal DNA evidence of the wild cat to corroborate the photograph. No reliable information was obtained on the occurrence of the snow leopard, common leopard, Pallas's cat, lynx, musk deer, ibex, urial or brown bear. The common palm civet was documented by both camera trap and faecal DNA evidence.

During the three camera-trap surveys eight large mammal species were photographed (including wild/domestic cat) in a total of 391 pictures in which the species could be identified (Table 1). Camera traps recorded the Indian crested porcupine most frequently $(55 \%$ of all pictures taken), followed by red fox (14\%), Asiatic black bear $(12 \%)$, golden jackal/grey wolf (10\%), common palm civet $(6 \%)$, wild or domestic cat $(<1 \%)$, yellow-throated marten $(<1 \%)$ and leopard cat $(<1 \%)$. An unidentifiable canid accounted for $1 \%$ of photographs. At the site where the goatskin was placed photographs captured yellow-throated marten and red fox over the 5-night period. The photographs did not allow definitive differentiation between grey wolf and golden jackal.

During the transect surveys six mammal species were sighted (because of identification uncertainties golden jackal and grey wolf are included together; Table 1). Two of these species, markhor and rhesus macaque, were not captured by the camera traps. For all species observed directly, multiple individuals were observed per sighting. The mean group size ranged from 1.5 \pm SD 0.71 (markhor) to $9.7 \pm$ SD 13.5 (rhesus macaque). Eighteen Asiatic black bears were observed on seven different occasions from late February until late May but not during transects surveyed in December.

Of the 201 scat specimens collected, 175 were identified and 26 failed to produce results. Due to short sequences and occasional lack of reference sequences against which to test samples it was often not possible to conclusively reach species identification for most samples. Genotyping indicated presence of red fox, Ursus, Canis, the Family Felidae, Paradoxurus and Hystrix (Table 1).

\section{Discussion}

This study, the first survey in the eastern forests of Afghanistan after 3 decades of war, indicates that some mammal species previously known from this area are extant despite threats from deforestation, habitat degradation, disruption of traditional natural resource 
TABle 1 Mammal species documented by camera traps, direct sighting or scat identification from December 2006 to March 2009 in Nuristan Province, Afghanistan (Fig. 1).

\begin{tabular}{|c|c|c|c|c|c|c|}
\hline Species & $\begin{array}{l}\text { No. } \\
\text { photographs }^{1}\end{array}$ & $\begin{array}{l}\text { Photos per } \\
100 \text { trap } \\
\text { nights }\end{array}$ & $\begin{array}{l}\text { No. } \\
\text { individuals } \\
\text { observed }\end{array}$ & $\begin{array}{l}\text { No. of } \\
\text { scats } \\
\text { identified }\end{array}$ & $\begin{array}{l}\text { Relative } \\
\text { abundance } \\
(\text { signs per } 10 \mathrm{~km})^{2}\end{array}$ & $\begin{array}{l}\text { Red List } \\
\text { Category } \\
\text { (year assessed) }\end{array}$ \\
\hline Red fox Vulpes vulpes & $17,19,19$ & 6.1 & 57 & 60 & 3.2 & LC (2008) \\
\hline Rhesus macaque Macaca mulatta & $0,0,0$ & 0 & 68 & 0 & 1.8 & LC (2008) \\
\hline $\begin{array}{l}\text { Golden jackal Canis aureus/grey wolf } \\
\text { Canis lupus }\end{array}$ & $11,20,9$ & 4.4 & 60 & 0 & 1.6 & LC (2008) \\
\hline Unknown Canis spp. & $2,1,0$ & 0.3 & 0 & 53 & 1.4 & \\
\hline Crested porcupine Hystrix indica & $45,34,138$ & 24.1 & 29 & 12 & 1.1 & LC (2008) \\
\hline $\begin{array}{l}\text { Asiatic black bear Ursus } \\
\text { thibetanus/brown bear Ursus arctos }\end{array}$ & $0,0,0$ & 0 & 0 & 24 & 0.7 & \\
\hline Asiatic black bear Ursus thibetanus & $0,45,0$ & 5.0 & 18 & & 0.5 & VU (2008) \\
\hline Unknown Felidae & $1,1,1$ & 0.3 & 0 & 16 & 0.4 & \\
\hline Markhor Capra falconeri & $0,0,0$ & 0 & 3 & 0 & 0.1 & EN (2008) \\
\hline $\begin{array}{l}\text { Common palm civet Paradoxurus } \\
\text { hermaphroditus }\end{array}$ & $0,9,13$ & 2.4 & 0 & 2 & 0.05 & LC (2008) \\
\hline Yellow-throated marten Martes flavigula & $0,2,1$ & 0.3 & 0 & 0 & 0 & LC (2008) \\
\hline Leopard cat Prionailurus bengalensis & $1,0,2$ & 0.3 & 0 & & 0 & LC (2008) \\
\hline $\begin{array}{l}\text { Domestic cat Felis catus/wild cat } \\
\text { Felis silvestris }\end{array}$ & $1,1,1$ & 0.3 & 0 & 0 & 0 & LC (2009) \\
\hline Total & $77,131,183$ & & & 167 & & \\
\hline
\end{tabular}

${ }^{1}$ August 2007 survey, November-December 2007 survey, January-March 2009 survey

${ }^{2}$ Signs include direct sightings and scats

management, and the absence of the rule of law. This is similar to results for post-conflict surveys in Afghanistan's remote north-east, Badakshan's Wakhan/Pamir, where Mishra \& Fitzherbert (2004) reported evidence of snow leopard, ibex, lynx, brown bear, wolf, Marco Polo sheep Ovis ammon polii and red fox. Our study also provides the first record of the common palm civet in Afghanistan (Kullmann, 1970; Petocz, 1972; Hassinger, 1973; Petocz \& Larsson, 1977; Petocz et al., 1977; Rodenburg, 1977; Habibi, 2003).

We did not obtain any reliable information on the occurrence of Pallas's cat, common leopard, lynx, snow leopard, ibex, musk deer, urial or brown bear. This could be partly explained by the limited experience of the survey teams and limited access to the most remote areas because of the security situation. It is questionable if ibex reaches the area surveyed; their seasonal movements between Badakshan and Nuristan take them to northern Nuristan during the winter but not as far south as our study site (Petocz \& Larsson, 1977). A satellite-collared snow leopard from Chitral Gol National Park in neighbouring Pakistan (Snow Leopard Trust, 2007; Chadwick, 2008) crossed the border to Nuristan in summer 2007. The collared female did not reach our study site, although community members reported that snow leopards still occur in the area. A more intensive camera-trap study may be needed to detect the common leopard in the study area. In comparison a study of Persian leopard Panthera pardus saxicolor in Iran's Bamu National Park, where leopard density is considered high, resulted in $>50$ leopard captures over 2,100 trap nights (Khorozyan, 2008). Community members in Nuristan commonly report livestock depredation by the common leopard. Those species most commonly documented by sighting, scat evidence and photographs are habitat and diet generalists that are often able to adapt to human presence (grey wolf/golden jackal, porcupine and red fox; Sever \& Mendelssohn, 1991; Jaeger, 2007).

Teams did not record the maturity of the sighted Asiatic black bears but it may be possible that the groups observed between February and May were mothers with cubs. This species is reported to mate in the late autumn, with young born from December to March (Roberts, 2005; Spady et al., 2007). A camera-trap photograph in November 2007 was of an adult bear with a young cub. Of the three camera-trap surveys that of November-December was the only one to capture Asiatic black bear. Of the 45 photographs, 34 were after nightfall. The limited number of studies of activity patterns of wild Asiatic black bears have, however, found them to be mostly diurnal (Schaller et al., 1989 in China; Hwang \& Garshelis, 2007 in Taiwan), with increased nocturnal activity in autumn (Reid et al., 1991; Hwang \& Garshelis, 2007). One scat sample was collected at 1,083 m in November. This may be because of the availability of mast foods at lower elevations, foraging for which has been documented for Asiatic black bears in China (Schaller et al., 1989; Reid et al., 1991). Further analysis is necessary to conclusively determine whether the scat samples belonged to Asiatic black bear or to the closely related brown bear. 
Both species inhabit a wide range of elevations. Asiatic black bear appears to be still widespread in the study area, although facing many threats (Ostrowski et al., 2009).

Evidence of the presence of markhor was scant but most camera traps were placed below $2,500 \mathrm{~m}$ in forests and relatively close to human settlements, outside the typical rugged and remote habitat of the species. In Nuristan, Petocz et al. (1977) and Petocz \& Larsson (1977) only occasionally observed single males in forested areas at lower elevations in August, probably because human activity restricted movement of markhor to higher elevations. Another possible reason for not photo-trapping markhor is the teams' tendency to locate camera traps along game routes and trails, which are potentially not areas frequented by markhor or other ungulates.

Leopard cats were found only during camera-trap surveys but further genetic analysis of the 16 felid scat samples may reveal more evidence of its occurrence. Leopard cats can now be found in Kabul's fur markets (K. Stevens, pers. obs.), contrary to the findings of Rodenburg (1977) who did not record its presence in these markets 30 years ago. Other studies have demonstrated the ability of leopard cats to persist despite disturbance, which may be a key factor in their continued presence in the eastern forests (Azlan \& Sharma, 2006; Rajaratnam et al., 2007), although the increasing occurrence of hides in Kabul's fur markets is of conservation concern.

Afghanistan's only primate, the rhesus macaque, was seen on seven occasions, primarily in the east and centre of the study area. The median group size of five was low compared to findings by Petocz \& Larsson (1977), who stated that local inhabitants reported group sizes of up to 30 animals, and Puget (1971) who observed group sizes of $80-180$, although the latter observations were north of our study site. On one occasion, teams found a group of 40; otherwise, the group sizes were $<8$. The observed low median group size could indicate a population decline, although macaques are reported to occur in a wide range of group sizes (8-180; Roonwal \& Mohnot, 1977). Formerly widely distributed throughout the provinces of Nuristan, Kunar and Paktya (Hassinger, 1973; Habibi, 2003), although in non-continuous populations, the species' natural habitat has been shrinking because of deforestation. Anecdotal evidence from the Kabul Zoo and military bases indicates that capture for the pet trade may also be a threat to the species (Aziz Gul Saqib, pers. comm.). There are no reliable estimates of the range or population status of this species in Afghanistan.

Verified photographs (Plate 1) and phylogenetic analysis of collected scats confirm the presence of the common palm civet in Nuristan. This constitutes a significant extension to the west of the species' known range. DNA analysis of two scats collected at 1,400 and $2,500 \mathrm{~m}$ were identified as Paradoxurus spp. Of the species of Paradoxurus the com-

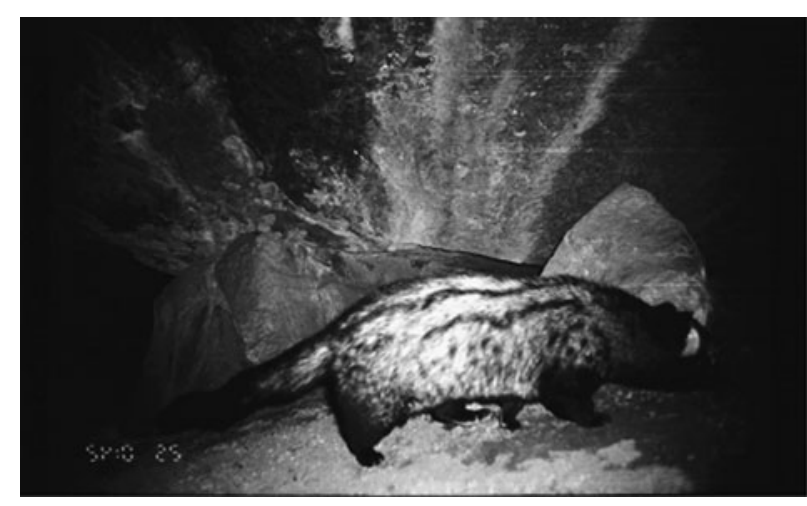

Plate 1 Camera-trap photograph of common palm civet Paradoxurus hermaphroditus from Nuristan Province.

Identification was confirmed by Dr Geraldine Veron, Museum National d'Histoire Naturelle, Paris, France.

mon palm civet $P$. hermaphroditus is the most likely to occur in Afghanistan as the others have limited ranges that are remote from this region (Nowak, 1999).

To our knowledge, there are no published live records of common palm civets in Afghanistan; the species was not listed by Habibi (2003) or Hassinger (1973). Thirty years ago a survey to assess the trade in wildlife skins in Afghanistan, involving a census of 26,420 furs, found furs, and manufactured products from furs, from two different civet species on the markets in Kabul (Rodenburg, 1977). One species was identified as a small Indian civet Viverricula indica (which shop owners claimed came from Pakistan), and the second species was suggested to be a common palm civet. Complete skins for the common palm civet were not observed in Kabul's markets but the fur pattern matched that reported for this species. Shopkeepers reported the origin of the palm civet furs as primarily Pakistan but that some skins were also obtained from Nuristan. Reports from Pakistan describe the range of $P$. hermaphroditus to be limited to the west of Kashmir in the northern areas (Sheikh \& Molur, 2004; Roberts, 2005). Although we have no further information regarding the species' distribution in Afghanistan, being forest-adapted it could be expected to occur along the eastern-forested belt of Afghanistan from Nuristan to northern Paktika Province. In Pakistan and Afghanistan the yellow-throated marten is reportedly hunted for its fur (Petocz \& Larsson, 1977; Roberts, 2005) and Rodenburg (1977) mentioned Nuristan to be the main source of furs of this species in Kabul's markets.

Threats to the environment in Afghanistan are manifold and opportunities for implementing conservation measures are limited, primarily by the security situation. The wildlife of Nuristan is afforded some protection because of the inaccessibility of much of the region, although the absence of the rule of law and collapse of traditional management practices during more than 30 years of conflict have allowed unregulated hunting and logging. Analysis of other 
post-conflict regions has demonstrated both positive and negative environmental outcomes as a result of conflicts (Nietschmann, 1990; Hatton et al., 2001; Draulans \& Van Krunkersven, 2002; Dudley et al., 2002). Post-conflict countries provide important opportunities to preserve species and societies together at a time when both are most vulnerable but where such efforts can have the greatest impact. WCS is implementing conservation programmes in Badakshan and Bamiyan Provinces of Afghanistan, and pursuing funding to continue research in Nuristan Province, focused on facilitating community-based monitoring and management of wildlife and forests.

\section{Acknowledgements}

This study was made possible by the generous support of the American people through the United States Agency for International Development (USAID). The contents of the article are the responsibility of the Wildlife Conservation Society and do not necessarily reflect the views of USAID or the United States Government. WCS teams undertook great personal risk in performing these surveys and, accordingly, we acknowledge our team members Abdul Zaher, Mohammad Joma, Abdul Ghafoor, Abdullah Nuristani and Abdul Haq for their leadership and commitment to conservation of Afghanistan's biodiversity. We also recognize Bahadur Khan, Ghulam Haider, Himmat, Jamal Khan and Abdul Qaher for their contribution to data collection and management. Surveys would not have been possible without the support of WCS country directors, Peter Smallwood and Dave Lawson, and WCS deputy director for the Asia program, Peter Zahler. We thank Srinivas Vaidyanathan and Devcharan Jathanna for their contributions in training and preparing field teams and Haqiq Rahmani for support with geographical information systems. Two anonymous reviewers made valuable comments and suggestions.

\section{References}

Azlan, J.M. \& Sharma, D. (2006) The diversity and activity patterns of wild felids in a secondary forest in Peninsular Malaysia. Oryx, 40, 36-41.

Chadwick, D. (2008) Out of the shadows. The elusive Central Asian snow leopard steps into a risk-filled future. National Geographic, 213, 106-129.

Draulans, D. \& Van Krunkersven, E. (2002) The impact of war on forest areas in the Democratic Republic of Congo. Oryx, 36, $35-40$.

Dudley, J.P., Ginsberg, J., Plumptre, A., Hart, J. \& Campos, L. (2002) Effects of war and civil strife on wildlife and wildlife habitats. Conservation Biology, 16, 319-329.

Foran, D.R. Crooks, K.R. \& Minta, S.C. (1997) Species identification from scat: an unambiguous genetic method. Wildlife Society Bulletin, 25, 835-839.
Global Land Cover Facility (2010) Http://www.landcover.org [accessed 26 October 2010].

Навіві, K. (2003) Mammals of Afghanistan. Zoo Outreach Organization, Coimbatore, India.

Hassinger, J. (1973) A survey of the mammals of Afghanistan, resulting from the 1965 Street Expedition (excluding bats). Fieldiana Zoology, 60, 1-195.

Hatton, J., Couto, M. \& Oglethorpe, J. (2001) Biodiversity and War: A Case Study of Mozambique. Biodiversity Support Program, Washington, DC, USA.

Henschel, P. \& Ray, J. (2003) Leopards in African Rainforests: Survey and Monitoring Techniques. Wildlife Conservation Society, Global Carnivore Program, Bronx, USA.

Hwang, M. \& Garshelis, D. (2007) Activity patterns of Asiatic black bears (Ursus thibetanus) in the Central Mountains of Taiwan. Journal of Zoology, 271, 203-209.

IUCN (2010) IUCN Red List of Threatened Species v. 2010.4. Http:// www.iucnredlist.org [accessed o8 November 2010].

JACKson, R.M., Roe, J.D., WAngChuK, R. \& Hunter, D.O. (2006) Estimating snow leopard population abundance using photography and capture-recapture techniques. Wildlife Society Bulletin, $34,772-81$.

Jaeger, M., Haque, E., Sultana, P. \& Brugger, R. (2007) Daytime cover, diet and space-use of golden jackals (Canis aureus) in agro-ecosystems of Bangladesh. Mammalia, 71, 1-10.

Joshi, A., Smith, J. \& Cuthiert, F. (1995) Influence of food distribution and predation pressure on spacing behaviour in palm civets. Journal of Mammalogy, 76, 1205-1212.

Khorozyan, I. (2008) Research and Conservation of the Persian Leopard Panthera pardus saxicolor in Bamu National Park, Fars Province, Iran. Plan 4 the Land, Tehran, Iran.

Kullmann, E. (1970) Die Tierwelt Ostafghanistans in ihren geographischen Beziehungen. Freunde des Kölner Zoo, 13, 3-25.

Mishra, C. \& Fitzherbert, A. (2004) War and wildlife: a postconflict assessment of Afghanistan's Wakhan Corridor. Oryx, 38, 102-105.

NCBI (2010) Genbank. Http://ww.ncbi.nih.gov/Genbank [accessed 26 October 2010].

Nietschmann, B. (1990) Conservation by conflict in Nicaragua. Natural History, 99, 42-49.

Now A K, R. (1999) Walker's Mammals of the World. 6th edition, Vol. 1. Johns Hopkins University Press, Baltimore, USA.

Ostrowski, S., Zahler, P., Dehgan, A., Stevens, K., Karlstetter, M. \& Smallwood, P. (2009) The Asiatic black bear still survives in Nuristan, Afghanistan. International Bear News, 18, 14-15.

Petocz, R. (1972) Report of the Laghman Markhor Survey. Afghan Tourist Organization, Kabul, Afghanistan.

Petocz, R. \& Larsson, J. (1977) Ecological Reconnaissance of Western Nuristan with Recommendations for Management. Food and Agriculture Organization of the United Nations, FO: DP/AFG/74/o16 Field Document No. 9, Kabul, Afghanistan.

Petocz, R., Skogland, T. \& Habibi, K. (1977) Conservation and Utilization of Wildlife Resources: Afghanistan. Food and Agriculture Organization of the United Nations, FO: DP/AFG/72/ 005 Interim Report, Rome, Italy.

Puget, A. (1971) Observations sur le macaque rhesus, Macaca mulatta (Zimmermann 1780), en Afghanistan. Mammalia, 35, 199-203.

Rajaratnam, R., Sunquist, M., Rajaratnam, L. \& Ambu, L. (2007) Diet and habitat selection of the leopard cat (Prionailurus bengalensis borneoensis) in an agricultural landscape in Sabah, Malaysian Borneo. Journal of Tropical Ecology, 23, 209-217. 
Reid, D., Jiang, M.D., TenG, Q.T., Qin, Z.S. \& Hu, J. (1991) Ecology of the Asiatic black bear (Ursus thibetanus) in Sichuan, China. Mammalia, 55, 221-237.

Roberts, T.J. (2005) Field Guide to the Large and Medium-Sized Mammals of Pakistan. Oxford University Press, Oxford, UK.

Rodenburg, W.F. (1977) The Trade in Wild Animal Furs in Afghanistan. Food and Agriculture Organization of the United Nations, FO: DP/AFG/74/o16 Field Document, Kabul, Afghanistan.

Roonwal, M.L. \& Mohnot, S.M. (1977) Primates of South Asia: Ecology, Sociobiology and Behavior. Harvard University Press, Cambridge, USA.

Schaller, G.B. \& Khan, S.A. (1975) Distribution and status of markhor (Capra falconeri). Biological Conservation, 7, 185-198.

Schaller, G.B., Qitao, T., Johnson, K.G., Xiaoming, W., Heming, S. \& Jinchu, H. (1989) The feeding ecology of giant pandas and Asiatic black bears in the Tangjiahe Reserve, China. In Carnivore Behavior, Ecology, and Evolution (ed. J.L. Gittleman), pp. 212-241. Comstock Publishing Associates, Ithaca, USA.

Sever, Z. \& Mendelssohn, H. (1991) Spatial movement patterns of porcupines (Hystrix indica). Mammalia, 55, 187-205.

SheikH, K.M. \& Molur, S. (eds) (2004) Status and Red List of Pakistan's Mammals. Based on the Conservation Assessment and Management Plan. IUCN, Islamabad, Pakistan.

Snow Leopard Trust (2007) Population Monitoring of Large Carnivores in Chitral Gol National Park, NWFP, Pakistan. Unpublished Report. Snow Leopard Trust, Seattle, USA.
Spady, T., Lindiurg, D. \& Durrant, B. (2007) Evolution of reproductive seasonality in bears. Mammal Review, 37, 21-53.

UNEP (United Nations Environment Programme) (2003) Afghanistan Post-Conflict Environmental Assessment. United Nations Environment Programme, Nairobi, Kenya.

Waits, L., Buckley-Beason, V., Johnson, W., Onorato, D. \& McCarthy, T. (2007) A select panel of polymorphic microsatellite loci for individual identification of snow leopards (Panthera uncia). Molecular Ecology Notes, 7, 311-314.

\section{Biographical sketches}

Kara STEVEns works on conservation in the midst of social and environmental change. Alex Dehgan uses science to improve diplomacy and development efforts in the USA and around the world. FARID RAWAN educates veterinary practitioners in Afghanistan. Muhammad Ismail Tawhid works on community-based wildlife monitoring and management in Afghanistan. Maria Karlstetter is a behavioural biologist with a background in applied conservation and research specializing in mountain and semi-arid desert ecosystems of the Central Asian region. Stephane Ostrowski works to bridge science, health and practical conservation. Husband and wife Jan Mohammad Ali and Rita Ali improve the livelihoods of their community in Central Nuristan through education and better management of natural resources. 